\title{
PENYUSUNAN LAPORAN KEUANGAN UNTUK KOPERASI PRODUSEN SRIKANDI MAJU BERSAMA
}

\author{
Ade Sandra Dewi ${ }^{1}$, Ani Pujiati ${ }^{2}$ \\ Universitas Sang Bumi Ruwa Jurai \\ adesandradewi@gmail.com,anipujiati@gmail.com
}

\begin{abstract}
Abstrak
Laporan keuangan berfungsi sebagai alat untuk meganalisis kinerja keuangan yang dapat memberikan informasi tentang posisi keuangan, kinerja dan arus kas, sehingga dapat dijadikan sebagai dasar dalam membuat keputusan ekonomi. Tujuan dari penulisan ini adalah untuk mengetahui pentingnya laporan keuangan dan perancangan laporan keuangan secara sederhana pada Koperasi Produsen Srikandi Maju Bersama Desa Ngarip, Ulubelu, Tanggamus. Penelitian menggunakan metode deskriptif kualitatif, pengambilan data dengan melakukan wawancara dan observasi langsung dengan pemilik koperasi tersebut. Penelitian ini menunjukkan bahwa terdapat kendala yang dialami oleh koperasi terutama dalam penyusunan laporan keuangan, dikarenakan kurangnya SDM yang memiliki kemampuan dalam bidang akuntansi dan kurangnya alokasi waktu dalam menyusun laporan keuangan. Menghadapi kendala tersebut Fakultas Ekonomi Universitas Sang Bumi Ruwai Jurai berupaya melakukan kegiatan pengabdian masyarakat dalam bentuk workshop pelatihan membuat laporan keuangan secara sederhana kepada pemilik koperasi tersebut. Pelatihan pembuatan laporan keuangan dilakukan untuk meningkatkan sistem pengelolaan yang baik pada suatu koperasi yang selanjutnya dapat menjadi acuan dalam pengambilan keputusan manajemen yang akurat.
\end{abstract}

Kata Kunci: Laporan keuangan, koperasi, Industri kopi

\begin{abstract}
The financial statements serve as a tool to analyze financial performance that can provide information about the financial position, performance and cash flow, so that can be used as a basis in making economic decisions. The purpose of this paper is to know the importance of financial statements and the design of simply financial statements on the cooperative convection desa Ngarip, Ulubelu, Tanggamus. The research used qualitative descriptive method, taking the data by conducting interview and direct observation with the owner of UMKM. This study shows that there are constraints experienced by cooperative, especially in the preparation of financial statements, due to lack of human resources who have the ability in the field of accounting and lack of time allocation in preparing financial statements. Facing the obstacles of the Faculty of Economics, University of Sang Bumi Ruwai Jurai seeks to do community service activities in the form of training workshops to make simple financial statements to the owners of cooperative. Training of financial reporting is done to improve the good management system at a cooperative which can then become reference in making accurate management decision.
\end{abstract}

Keywords: Financial Report, Cooperative, Industrial Cofee

\section{PENDAHULUAN}

Ulu Belu terkenal dengan kopi. Secara keseluruhan, ada 10.786 hektar perkebunan kopi di Ulubelu dengan total produksi 5.970 ton per tahun. Kopi yang diproduksi petani Lampung adalah jenis kopi robusta yang memiliki citra rasa berbeda karena ditanam dilahan vulkanik.

Produksi kopi robusta diwilayah ini banyak dibeli dari petani ke beberapa perusahaan besar. Disayangkan kondisi ini tidak didukung oleh produksi kopi yang dikelola oleh 
masyarakat sebagai alternatif ekonomi. Sebagian besar masyarakat membeli kopi bubuk untuk memenuhi kebutuhan rumah tangga, mereka membeli dari luar daerah.

Peran perempuan sebagai penggerak pemberdayaan masyarakat desa saat ini telah banyak dilakukan seiring dengan semakin menguatnya partisipasi mereka dalam berbagai bidang kehidupan. Perempuan mampu menjadi motor penggerak yang kuat jika diberikan peran untuk mengambil bagian dalam proses pembangunan masyarakat. Hal inilah yang ditunjukkan oleh kelompok perempuan Srikandi di Desa Ngarip, Kecamatan Ulubelu, Kabupaten Tanggamus, Lampung.

Bermula dari keinginan kelompok wanita tani (KWT) yang merupakan lulusan Sekolah Lapang Pertanian Kopi Organik yang diadakan oleh WWF Indonesia di tahun 2012 ini untuk memproduksi kopi bubuk yang selama ini mereka beli dari daerah lain. Kelompok ini berdiri sejak 2 Agustus 2015 dengan jumlah anggota sebanyak 18 orang. Saat ini KSU Srikandi telah beranggotakan 160 orang yang terdiri dari 140 perempuan dan 20 laki-laki. Kelompok ini memiliki visi untuk mewujudkan lembaga sosial ekonomi yang mandiri dan berdaya saing sebagai penggerak ekonomi pedesaan yang berwawasan lingkungan dan berkelanjutan. Saat ini kelompok Srikandi telah memiliki badan hukum koperasi dengan nama Koperasi Produsen Srikandi Maju Bersama.

Kelompok ini bergerak di bidang usaha simpan pinjam dengan jumlah simpanan mencapai 256.312.000 Rupiah dan pinjaman sejak berdiri telah mencapai 1.132.000.000 Rupiah. Selain itu, kelompok ini memiliki unit usaha kopi bubuk Srikandi yang telah mampu memproduksi 1.382 kilogram kopi bubuk pertahun yang diharapkan di tahun 2018 bisa meningkat menjadi 1.800 kilogram.

Berbekal pengalaman dan pengetahuan yang diperoleh melalui serangkaian pelatihan yang difasilitasi oleh WWF dan mitra lainnya, antara lain: Pelatihan Barista di Bandar Lampung, Pameran Kemah Konservasi Lampung, Workshop GEMASKOP di Kabupaten Tanggamus, Worskop Sosialisasi Lembaga Keuangan Mikro di Tanggamus, Pelatihan Kewirausahaan Perempuan Pedesaan di Yogyakarta, Pameran Pekan Raya Nusantara (PARARA) di Jakarta, Pelatihan Hak Kekayaan Intelektual (HAKI) di Provinsi Lampung, dan Pelatihan Pengelolaan Dana Hibah di Bandar Lampung, saat ini Srikandi telah mampu berbagi pengalaman dengan menjadi fasilitator bagi kelompok usaha di desa sekitarnya. Saat ini di Kecamatan Ulubelu telah terbentuk 4 KSU perempuan, antara lain KSU Sumatra Sukamaju (jumlah anggota sebanyak 64 orang dan jumlah simpanan 62 juta), KSU Sumber Rezeki Datarajan (jumlah anggota 45 orang dan jumlah simpanan 124.320.000), dan KSU Mekar Sari Air Abang (jumlah anggota 23 orang dan jumlah simpanan 9,5 juta). Ini tentu menjadi hal yang menarik karena kelompok perempuan di Ngarip telah mampu memberikan efek domino bagi perempuan dari desa lain untuk turut membangun kelompok usaha dalam rangka pembangunan ekonomi masyarakat pedesaan.

Usaha kelompok perempuan ini bukan berarti berjalan tanpa masalah. Mereka masih menghadapi beberapa kendala seperti kurangnya pemahaman mengenai laporan keuangan, kurang tersedianya tenaga profesional dalam hal pembukuan, keuangan, dan kelembagaan yang belum tertata. Pengurus Koperasi ini berprofesi sebagai petani kopi yang berpendidikan lulusan Sekolah Dasar (SD) sehingga merupakan kendala dalam pembukuan dan penyusunan laporan keuangan karena keterbatasan pengetahuan mereka. Namun mereka merasa punya peluang yang besar dalam pengembangan usaha ke depan karena 
berlimpahnya bahan baku kopi dan keunikan citarasa kopi yang mereka miliki. Pengembangan usaha tersebut lebih menuntut untuk pengolahan yang lebih profesional.

Jargon KSU Srikandi yang berharap kelompok sebagai Ikatan pemersatu masyarakat Desa Ngarip merupakan bukti bahwa modal sosial masih kuat dan masih terjaga di desa ini. Serangkaian pelatihan dan pendampingan diharapkan bisa semakin menguatkan hal itu untuk membangun cita-cita bersama dalam upaya menjaga kelestarian hutan di sekitar desa dan mewujudkan prinsip-prinsip pembangunan ekonomi yang berkelanjutan. Kelompok usaha ini berupaya untuk meningkatkan nilai-nilai kearifan lokal dan menggunakan sistem pertanian yang berkelanjutan untuk menunjang produktivitas kopi yang lestari, serta memanfaatkan sumber daya alam yang mempunyai nilai ekonomi yang berkelanjutan. Hal ini sejalan dengan upaya Universitas Sang Bumi ruwai Jurai dalam mendukung upaya pembangunan berkelanjutan masyarakat.

\section{METODOLOGI PENELITIAN}

\section{A. Khalayak Sasaran}

Khalayak sasaran dalam kegiatan pengabdian adalah para pengelola koperasi. Diamana pengurus yang terkait dengan keuangan dan laporan keuangan. Pelatihan dibatasi jumlah pesertanya agar peserta pelatihan dapat belajar secara kondusif dan peserta dapat lebih terbuka.

\section{B. Metode Penerapan Ipteks}

Metode yang digunakan dalam kegiatan pelatihan ini sebagai berikut:

1. Metode ceramah digunakan oleh pemateri unuk menjelaskan materi yang berkaitan dengan materi pengelolaan keuangan koperasi.

2. Metode diskusi digunakan untuk memperdalam materi bahasan baik bentuk tanya jawab secara perorangan maupun perwakilan peserta.

3. Metode pemberian motivasi dalam bentuk permainan berkelompok.

\section{Keterkaitan}

Kegiatan pengabdian ini terkait dengan program pembangunan perekonomian masyarakat daerah khususnya Desa Ngarip untuk meningkatkan kesejahteraan masyarakat. Hasil kegiatan ini diharapkan dapat memberikan kontribusi pengetahuan para peserta untuk dapat menyusun laporan keuangan koperasi dengan baik. Lembaga yang menangani kegiatan pengabdian ini adalah lembaga Pengabdian Masyarakat Universitas Sang Bumi Ruwai Jurai dalam rangka mewujudkan Tridharma Perguruan Tinggi.

\section{Rancangan evaluasi}

Evaluasi dalam kegiatan ini dilaksanakan dalam tiga tahap yakni

1. Tahap perencanaan kegiatan. Pada awal kegiatan ini, pemateri menjelaskan tentang materi yang akan disampaikan.

2. Tahap selama proses kegiatan. Berdasarkan materi yang telah disampaikan peserta diberikan waktu dalam bertanya serta diskusi masalah yang berkaitan dengan materi. 
3. Tahap akhir kegiatan. Evaluasi pada akhir kegiatan ini dilakukan untuk mengukur keberhasilan dari seluruh program pelatihan ini. Evaluasi dilakukan melalui penilaian berdasarkan data di lapangan, Nampak bahwa para peserta pelatihan memahami penjelasan materi yang disampaikan. Hal ini terbukti dengan berbagai macam pertanyaan yang diajukan.

\section{E. Jadwal pelaksanaan}

Pelaksanaan pelatihan ini selama satu hari pada tanggal 30 September 2019 di Sekretariat Koperasi Koperasi Produsen Srikandi Maju Bersama. Desa Ngarip, Kecamatan Ulubelu, Kabupaten Tanggamus, Lampung, pukul 08.00-15.00.

\section{HASIL DAN PEMBAHASAN}

\section{A. Gambaran Umum Lokasi}

Bagian ini mengemukakan gambaran umum lokasi dan data yang diperoleh selama pelaksanaan kegiatan pengabdian kepada masyarakat (PPM). Kegiatan ini dilakukan dengan menggunakan metode permainan, ceramah,tanya jawab dan diskusi. Kegiatan ini merupakan pengabdian dalam rangka menumbuhkan minat dan kesadaran para pengelola Koperasi Produsen Srikandi Maju Bersama. Desa Ngarip, Kecamatan Ulubelu, Kabupaten Tanggamus, Lampung untuk dapat menghitung dan menyusun keuangan secara benar dan transparan serta bertanggungjawab dalam upaya meningkatkan laba usaha koperasi.Sebagaimana yang telah dikemukakan sebelumnya bahwa yang menjadi lokasi kegiatan pelatihan adalah di Koperasi Produsen Srikandi Maju Bersama. Desa Ngarip, Kecamatan Ulubelu, Kabupaten Tanggamus, Lampung

\section{B. Peserta Pelatihan}

Pelatihan ini diikuti oleh peserta dari Koperasi Produsen Srikandi Maju Bersama. Desa Ngarip, Kecamatan Ulubelu, Kabupaten Tanggamus, Lampung. Peserta berasal dari pengurus keuangan yang terkait keuangan, laporan keuangan, dan pengurus yang terkait akses ke rekening koran di Bank.

\section{Capaian Hasil Kegiatan}

Berdasarkan hasil survey dan konsultasi dengan ketua koperasi maka pada tanggal 30 September 2019 telah dilaksanakan kegiatan sosialisasi dan pelatihan keuangan laporan keuangan koperasi, dalam meningkatkan pemahaman para pengelola koperasi dalam membuat laporan keuangan Koperasi Produsen Srikandi Maju Bersama. Desa Ngarip, Kecamatan Ulubelu, Kabupaten Tanggamus, Lampung

Peserta pelatihan pada tahap awal (sesi pagi), diberikan materi tentang laporan keuangan koperasi berupa Rencana Anggaran Biaya, Buku Bank, dan Buku Besar. Peserta pada tahap kedua (sesi siang) diberikan pelatihan penyusunan laporan keuangan, Buku Pembantu Advance, Buku Pembantu Biaya, Buku Kas Kecil (jikaada), dan Rekonsiliasi Bank. Setelah itu para peserta diajak berdialog dengan tanya jawab menyangkut materi yang telah disampaikan. Sedangkan hasil evaluasi yang telah dilakukan untuk mengukur tingkat keberhasilan program kegiatan pengabdian ini, dapat dijabarkan sebagai berikut: 
1. Pengetahuan serta serta minat dari para pengelola usaha Koperasi Produsen Srikandi Maju Bersama. Desa Ngarip, Kecamatan Ulubelu, Kabupaten Tanggamus, Lampung tentang materi laporan keuangan.

2. Tingkat pengetahuan dan pemahaman para pengelola usaha Koperasi Produsen Srikandi diukur dengan partisipasi yang berkembang dalam tanya jawab dan praktek ilustrasi pelatihan perhitungan contoh soal kasus penyusunan laporan keuangan koperasi.

3. Berdasarkan data di lapangan nampak bahwa para peserta kegiatan pelatihan sangat memahami penjelasan materi yang disampaikan. Hal ini dibuktikan dengan berbagai macam pertanyaan yang diajukan serta diskusi.

\section{KESIMPULAN DAN SARAN}

\section{Kesimpulan}

Berdasarkan penelitian tersebut dapat ditarik kesimpulan bahwa pencatatan transaksi keuangan yang dilakukan sampai saat ini hanya pencatatan terhadap kas masuk dan kas keluar dari hasil penjualan dan pembelian. Prosedur pencatatan juga belum dilakukan secara baik, dimana bukti transaksi belum diarsipkan secara terstruktur, sehingga dikhawatirkan mengalami kesulitan bila akan dibutuhkan. Sedangkan kendala dalam penyusunan laporan keuangan sampai saat ini adalah belum adanya sumberdaya manusia yang mampu menyusun laporan keuangan, dikarenakan SDM yang tersedia memiliki keterbatasan pendidikan, dengan latar pendidikan lulusan SD.

Pelatihan Penyusunan Laporan Keuangan berjalan sangat aktif dan komunikatif. Awal pelatihan diberikan permainan untuk meningkatkan motivasi terhadap peserta yang merupakan pengurus yang terkait dengan keuangan koperasi. Materi diberikan mengenai pemahaman laporan keuangan dan tujuan adanya laporan keuangan agar peserta mengetahui pentingnya laporan keuangan. Setelah itu diberikan materi yang yang terkait kasus laporan keuangan yang terdiri dari : Rencana Anggaran Biaya, Buku Bank, Buku Besar, Buku Pembantu Advance, Buku Pembantu Biaya, Buku Kas Kecil (jika ada), dan Rekonsiliasi Bank. Alhamdulillah pada pelaksanaannya para peserta memahami materi terlihat dengan antusiasnya peserta dalam berdiskusi dan pengerjaan kasus.

\section{DAFTAR PUSTAKA}

Fees Warren. (2014). Accounting Pengantar Akuntansi. Jakarta: Salemba Empat.

Harahap, Sofyan Syafri. (2018). "Analisis Kritis Atas Laporan Keuangan". Jakarta RajaGrafindo Persada

Hendriksen dan Brenda. (2014) . Teori Akunting. Interaksara: Tanggerang.

Ikatan Akuntansi Indonesia. (2018). Standar Akuntansi Keuangan, PSAK No.1: Penyajian Laporan Keuangan .Jakarta : Salemba Empat.

Kusnadi, Hendar.(2017). Ekonomi Koperasi Edisi 2. Jakarta: Universitas Indonesia. 
Seminar Nasional Penelitian dan Pengabdian kepada Masyarakat Universitas Sang Bumi Ruwa Jurai Tahun 2020

Munawir.(2014) Analisa Laporan Keuangan Cet. 15. Yogyakarta : Liberty.

www. Depkop.go.id 